\title{
DE PARINTINS PARA TODO MUNDO VER OS VELHOS DA AMAZÔNIA
}

\author{
Alice Alves de Menezes Ponce de Leão Nonato ${ }^{1}$
}

\section{Introdução}

A velhice é um destino inevitável para o qual caminham todos os humanos, com exceção daqueles que morrem antes de atingi-la (Leão, 2015). Embora imponha traços físicos e psicológicos comuns a todos indistintamente, a velhice não é uma condição unificadora, pois é vivida de formas diferentes pelos indivíduos, fazendo com que exista uma pluralidade de velhices, sendo a cultura um dos principais fatores que exerce influência sobre a diversidade de experiências de ser velho² ${ }^{2}$

A Amazônia não é, apenas, o berço da biodiversidade, é, também, o lugar da sociodiversidade. A formação social desta região estabeleceu formas específicas do indivíduo se relacionar com os outros e com a natureza a partir de traços culturais híbridos resultantes da fusão dos povos indígenas que já viviam neste lugar e de outros que colonizaram a região, especialmente os europeus e, depois, os nordestinos que chegaram durante o período da borracha.

Os processos de modernização que atingiram algumas cidades da Amazônia modificaram os modos de vida da população, principalmente das pessoas que vivem nas capitais que se tornaram grandes metrópoles. Mas, as cidades do interior do Amazonas, especialmente aquelas mais afastadas da capital Manaus, ainda guardam fortes resquícios tradicionais, como a cidade de Parintins, localizada a $369 \mathrm{~km}$ da capital. Apesar da distância geográfica, Parintins ${ }^{3}$ é a segunda cidade do Amazonas em termos populacionais, contando com mais de 100 mil habitantes, e ocupa, também, a segunda posição em número de velhos, sendo 7.153 pessoas com 60 anos e mais (IBGE, 2010).

\footnotetext{
${ }^{1}$ Universidade Federal do Amazonas, UFAM.

2 O uso do termo "velho" neste texto é aplicado no sentido de referir-se ao indivíduo que atingiu a condição existencial da velhice e tornou-se velho. O uso reiterado da palavra se dá na perspectiva de naturalizar o termo como algo natural isento de qualquer atributo pejorativo.

${ }^{3}$ Parintins ganhou projeção mundial e nacional em razão do festival folclórico dos bois-bumbás garantido e caprichoso que acontece todo ano no mês de junho. É possível chegar a Parintins por via fluvial através de barco de linha, em que a duração de viagem é de um dia ou por meio de lancha, com oito horas de viagem, mas também, por via aérea com uma hora de voo.
} 
Parintins é daquelas cidades em que o tradicional e o moderno coexistem no mesmo tempo e espaço em virtude do nível de desenvolvimento capitalista e da precariedade das políticas públicas oferecidas à população.

Em um país pluriétnico como o Brasil, a elaboração das velhices se dá de formas diferentes não só de um estado em relação a outro, mas também dentro de um mesmo estado, como é possível observar no Amazonas quando comparamos a capital Manaus com Parintins, uma cidade do interior. Se não bastasse isso para acentuar as diferenças nas formas como os indivíduos de cada um desses lugares vivem as suas velhices, encontramos também singularidades de vivências dessa condição existencial por indivíduos que vivem dentro de uma mesma cidade, mas que ocupam o espaço urbano e outros que habitam a área rural, sobretudo em comunidades afastadas do perímetro urbano.

Pensando nisso, escolhemos como lócus desta pesquisa as comunidades rurais de Caburi, Vila Amazônia, Mocambo e Zé Açú que se situam dentro do município de Parintins. Nestes lugares com pouca infraestrutura urbana, os velhos são pessoas que preservam e perpetuam saberes e práticas arraigados em um contexto geracional marcado pelo tradicionalismo rural amazônico. Esses saberes se forjam como alternativas de sobrevivência, seja no campo do trabalho, da saúde e na constituição das redes de sociabilidade e solidariedade evocando, muitas vezes, o imaginário popular como forma de preservação do meio e garantia de manutenção da vida.

As práticas sociais dos velhos de Parintins contribuem para delinear a poiesis ${ }^{4}$ da vida na velhice na Amazônia imprimindo contornos específicos nas formas como os velhos se relacionam com o meio, com os outros e como ressignificam continuamente as suas velhices a partir de interações sociais e simbólicas em torno dos elementos míticos que compõem o imaginário do povo que vive nessa região singular.

Para preservar a identidade dos sujeitos entrevistados, escolhemos atribuir aos homens nomes de pássaros e às mulheres, nomes de flores. Este texto propõe uma discussão em torno do objetivo de compreender as formas como os velhos das comunidades rurais de Parintins elaboram as suas vidas na velhice. Esta pesquisa

\footnotetext{
${ }^{4} \mathrm{O}$ sentido de "poiesis" referendado neste texto alude ao entendimento de "modo de vida" enquanto um tipo de organização que, na perspectiva aludida por Maturana e Varela (2001), se processa a partir da inter-relação do homem com o meio em que vive, tanto no sentido de que o meio exerce influência sobre o homem, mas, também, o homem exerce influência sobre o meio ao interagir com ele.
} 
incursiona por uma abordagem interdisciplinar, de natureza qualitativa, que privilegiou relatos de homens e mulheres com idades a partir de sessenta anos. A incursão deste debate na perspectiva interdisciplinar ancora-se na abordagem de Morin (2012) para quem o conhecimento é tecido junto em uma teia que se inter-relaciona entre o indivíduo e o meio em que vive. No primeiro momento deste trabalho, propomos uma breve caracterização das comunidades rurais de Parintins que serviram como lócus da pesquisa e no segundo momento, apresentamos a poiesis da vida dos velhos no contexto amazônico parintinense.

\section{Caracterização etnográfica das comunidades rurais de Parintins, Amazonas}

As águas barrentas do rio Amazonas levam a lugares afastados e estreitos onde se escondem os segredos e os mistérios que permeiam a vida de um povo longevo, que tem muita história para contar porque já viveu muito naquele lugar.

A algumas horas de Parintins, as pequenas embarcações ${ }^{5}$ livram-se da extensão do grande rio ao entrar em pequenos leitos que levam às Agrovilas ${ }^{6}$ de São Sebastião do Caburi e de São João do Mocambo ou quando a balsa ${ }^{7}$ atravessa até chegar à comunidade de Vila Amazônia, de onde se segue em estrada de terra ou em viagem de lancha até a comunidade de Bom Socorro do Zé Açú.

Localizada a 60 km do município de Parintins, está a agrovila de São Sebastião do Caburi com uma população de 2.112 habitantes (Silva, 2009). Caburi fica a cinco horas de barco partindo de Parintins e conta com serviços semelhantes aos que existem na área urbana. Possui infraestrutura parecida com a da área urbana de Parintins, no sentido de contar com abastecimento de água encanada, energia elétrica, sistema de saúde primário, escola municipal, praça, pousadas, restaurante, mercado, comércios e um pequeno porto para atracação de embarcações. Entretanto, não possui serviço de telefonia móvel.

O distrito de Caburi possui várias comunidades em seu entorno, mas limitamonos à agrovila de São Sebastião. São Sebastião do Caburi tem uma dinâmica de vida

\footnotetext{
${ }^{5}$ Referimo-nos às lanchas e às rabetas que servem como transporte fluvial rápido entre comunidades rurais próximas.

${ }^{6}$ Agrovilas são comunidades que se situam na mediação territorial entre a área urbana e a área rural.

${ }^{7}$ Transporte fluvial comum na Amazônia semelhante a um barco que transporta veículos e pessoas.
} 
pacata e simples. Esse ritmo de vida se altera no período das festividades, principalmente, com a festa do Brilho do Banzeiro no verão amazônico em que a estação seca propicia a formação de lindas praias de areia branca e águas escuras à frente da pequena cidade, e as festividades da igreja católica, especialmente os festejos para o santo padroeiro do lugar, São Sebastião.

De acordo com Silva (2009), festejos para o santo católico São Sebastião estão contextualizados dentro de uma promessa feita por Dona Caranã, uma senhora que junto com o seu marido desbravou Caburi com um terçado ${ }^{8}$ em busca de terras férteis para a agricultura. Cansada de dois surtos de malária que dizimou grande parte da população, Dona Caranã fez uma promessa a São Sebastião pedindo para cessar a peste e as mortes naquele lugar. Se ela fosse atendida, prometera confeccionar a imagem do Santo e rezar ladainhas em sua homenagem todos os anos. Suas preces foram ouvidas. "Em 1960, o santo passa a ser festejado de modo diferente, com celebração de novenas, reza de terço, festejo de arraial e outras atividades, pois o santo passa a ser padroeiro da Congregação Mariana, movimento religioso que se estabeleceu no lugar” (Silva, 2009: 83).

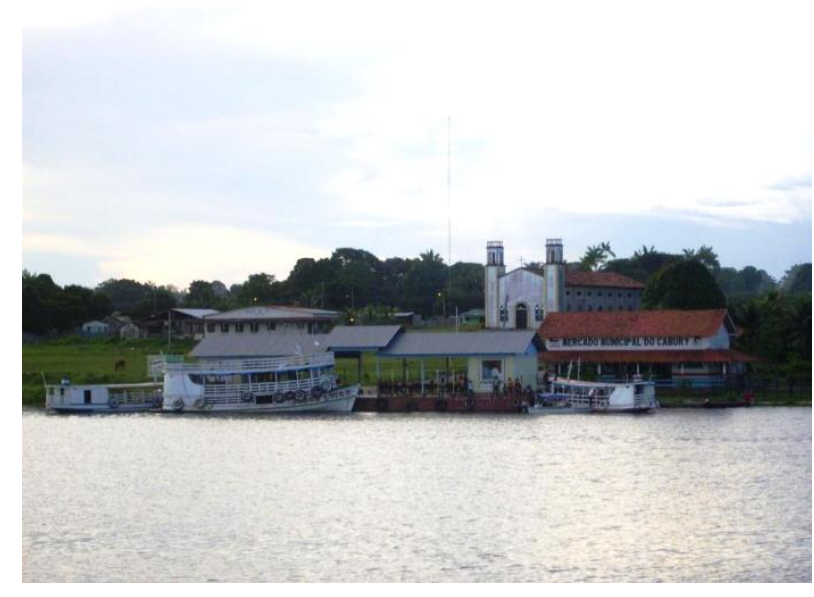

Figura 1 - Porto da Agrovila de São Sebastião do Caburi Pesquisa de Campo. Parintins, Amazonas, 2016.

Da agrovila de São Sebastião do Caburi, seguindo durante uma hora de estrada de barro, chega-se até a agrovila de São João Batista do Mocambo. Com uma população de 1.948 habitantes, Mocambo leva esse nome porque os moradores costumavam se esconder nas matas e os índios em suas malocas por medo dos revolucionários cabanos, que faziam uso da violência e da brutalidade (Silva, 2009).

\footnotetext{
${ }^{8}$ Facão utilizado, dentre outras finalidades, para desbravar a mata através do corte de galhos de árvores.
} 
O Distrito de Mocambo do Arari está composto geograficamente pela Agrovila de São João Batista, Comunidade de Nossa Senhora de Lurdes, São Tomé, Santo Antônio, São Pedro, Remanso, Monte Sinai, Anjo da Guarda, Arquinho, Costa do Arco, Borralho, Guaribas, Saracura e Ilha das Onças.

São João Batista do Mocambo conta com uma infraestrutura urbana e de serviços, possui ruas e avenidas pavimentadas e nomeadas. Em sua extensão, possui pequenas escadarias para atracação de embarcações, assim como uma rampa principal para embarque e desembarque, com acesso direto à capital do estado, Manaus.

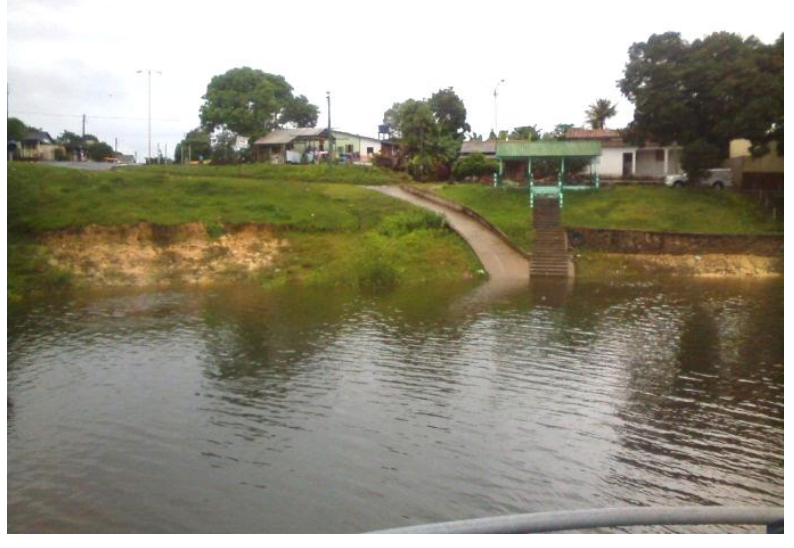

Foto 2 - Escadaria da agrovila de São João do Mocambo Pesquisa de Campo. Parintins, Amazonas, 2016.

A agrovila possui uma escola estadual e outra municipal, um centro de convivência do idoso desativado, comércios, atenção primária à saúde, motos, carros, praças, restaurantes, pousadas, serviço de abastecimento de água encanada e energia elétrica. Mas, não possui serviços de telefonia móvel, contudo grande parte da comunidade dispõe de acesso à internet através das redes comercializadas de wifi espalhadas pela comunidade.

Dentre os festejos do Mocambo, um se assemelha ao que Festival Folclórico dos bois-bumbás Garantido e Caprichoso ${ }^{9}$, que acontece na cidade de Parintins. É o Festival do Mocambo que conta com a disputa dos bois Espalha Emoção e Touro Branco, realizado no mês de julho, no Centro Cultural Victor Mendonça ou Arena

\footnotetext{
${ }^{9}$ Manifestação cultural folclórica que ocorre todo ano no mês de junho na cidade de Parintins, Amazonas, com projeção e reconhecimento mundiais, e que consiste na disputa dos bois-bumbás Garantido (vermelho) e Caprichoso (azul) na arena do bumbódromo onde são contadas a vida do povo amazônico em forma de toadas (ritmo musical).
} 
Mocambodrómo, palco dos três dias de festa. Além dele, há o Festival do Beiju ${ }^{10}$ e as festas religiosas, principalmente católicas, já que a agrovila surgiu como “Congregação Mariana (movimento religioso da Diocese de Parintins), em 17 de abril de 1964” (Silva, 2009: 81).

Distante do distrito de Mocambo e bem perto da cidade de Parintins, a 5 km, está localizada a comunidade de Vila Amazônia, ocupada por 3.115 habitantes (Silva, 2009). Vila Amazônia possui tráfego fluvial para Parintins todos os dias através de lanchas e balsa, intensificado nos finais de semana em razão do atrativo dos balneários que prometem relaxar quem está cansado da rotina da cidade.

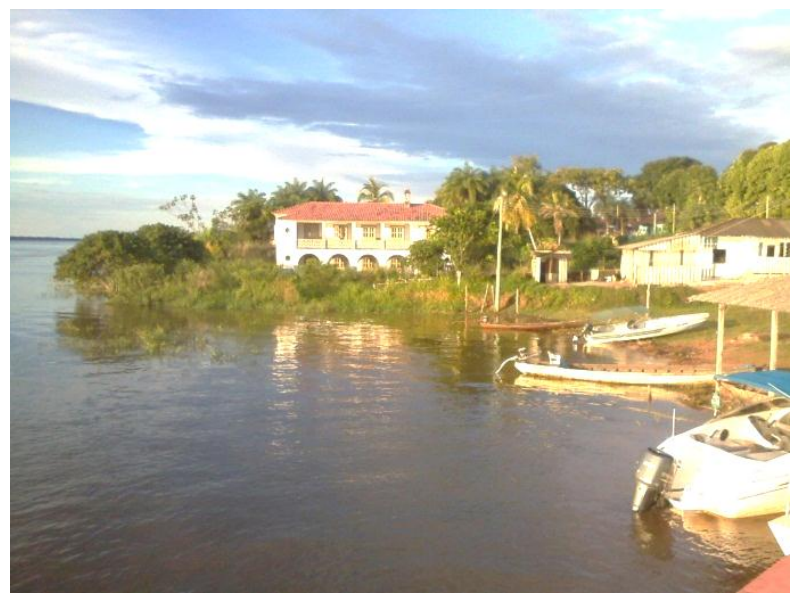

Foto 3 - Vista de entrada da Vila Amazônia

Pesquisa de Campo. Parintins, Amazonas, 2016.

A comunidade possui serviços de telefonia móvel, comércios, escolas, atenção primária à saúde, ruas e avenidas pavimentadas, serviços socioassistenciais, estradas com acesso a comunidades e ao município de Juruti, no estado do Pará. A gleba de Vila Amazônia ainda guarda traços marcantes da presença nipônica que a desenvolveu e colonizou, como o “casarão”, deteriorado pelo abandono do poder público.

Segundo Silva (2009), os emigrantes japoneses chegaram à Vila Amazônia (que se chamava Vila Batista) em 1930. Peru e Estados Unidos eram os principais países para onde os japoneses emigravam. Mas, problemas com o excesso de estrangeiros dificultaram a imigração fazendo com que eles fossem atraídos para o Brasil. Nesse período, os estados do Pará e do Amazonas viviam o declínio da borracha e a preocupação com o futuro de suas economias.

\footnotetext{
${ }^{10}$ É um alimento feito à base de farinha de mandioca que se mistura com água e sal e depois essa mistura é assada em um tacho de ferro, resultando em um tipo de biscoito com consistência de sequilho.
} 
A imigração japonesa na Amazônia surgiu como uma esperança para a recuperação da economia na região. Essa esperança estava depositada em um acordo entre o governo brasileiro e os japoneses para o desenvolvimento de um projeto agrícola derivado de um produto de fácil cultivo e forte demanda.

Vila Amazônia (antiga Vila Batista) foi escolhida pela facilidade de escoamento da produção tanto para a capital do Amazonas, Manaus, como para a capital do estado do Pará, Belém, e pelo solo indicado para a cultura da juta. O responsável pelo projeto foi Tukasa Uetsuka, que idealizou a construção do Instituto Amazônia, um pólo de pesquisa e estudo sobre a hidrologia do rio Amazonas e o solo tropical.

Enquanto deixava alguns técnicos para o desenvolvimento das atividades, Uetsuka voltou para o Japão para buscar os Koutakuseis, egressos da Escola Superior de Emigração Japonesa, que tinham entre 19 e 20 anos. Silva (2009: 76) explicita que a partir de então

\footnotetext{
A floresta virgem começou a ceder espaço para instalações de vários tipos de instalações industriais: serrarias, usinas de beneficiamento do pau-rosa, olaria, fábrica de mosaico, beneficiamento de arroz em larga escala, fábrica de farinha totalmente mecanizada e um engenho para a fabricação de aguardente e mel de cana.
}

A juta era utilizada para a fabricação de sacos para armazenagem de diferentes produtos. Mas, as primeiras mudas de juta não atingiram o tamanho necessário para a colheita, desanimando os japoneses. Mas, Riota Oyama trouxe de seu sítio localizado em uma área de várzea uma muda de juta bem-sucedida, cujas sementes atingiram a expectativa esperada e alavancaram a produção.

A produção impulsionou o desenvolvimento de Vila Amazônia, que de uma vila com infraestrutura precária e sem recursos, passou a ganhar hospital, escola, estação experimental, posto meteorológico, armazéns e médicos vindos do Japão.

Mas, a intenção de transformar Vila Amazônia em um núcleo japonês ameaçava a sociedade parintinense, que via os costumes japoneses como rigorosos, principalmente no que se refere ao casamento, restrito apenas entre os próprios nipônicos. Quem violasse a regra estaria passível de banimento da sociedade japonesa.

Além disso, o crescimento agrícola passou a ser motivo de desconfiança e desagrado pelos brasileiros que não concordavam com o fato de estrangeiros fazerem 
fortuna e tornarem-se reis em terras alheias. A insatisfação começava a incomodar os brasileiros a ponto de ter quem quisesse se mobilizar para tentar anular o domínio das terras aos japoneses.

Durante a Segunda Guerra Mundial (1939-1945), o Brasil cortou relações diplomáticas com o Japão. O exército se deslocou para a Amazônia para prender os japoneses que se encontravam na Vila Amazônia. Vários koutakusseis fugiram pelas matas e as várzeas e os que foram capturados, foram levados para o estado do Pará, onde ficavam os prisioneiros de guerra.

Vila Amazônia passa a ser reapropriada pelo governo brasileiro. Em 1946, o patrimônio que restou foi leiloado a uma empresa que tinha sede em Manaus, a CIA J. G. Araújo S.A., que através do cultivo de outras plantações e da pecuária resultou na depredação da comunidade.

Silva (2009) refere que depois da administração da J.G. Araújo, Vila Amazônia passou por várias fases até ser desapropriada pelo Instituto Nacional de Colonização e Reforma Agrária (INCRA) em 1988 para ser área de assentamento agrário. Os japoneses foram os primeiros a modificar a paisagem do lugar. Na atualidade, só restam as ruínas no local que concentra o maior contingente populacional daquele território.

Passando a frente de Vila Amazônia ou seguindo um pouco mais de uma hora por estrada de terra, encontra-se a comunidade de Bom Socorro do Zé Açú, com 1.200 habitantes distribuídos em 230 famílias (SILVA, 2015). Possui abastecimento de água encanada, energia elétrica, escolas, comércios, igrejas, posto de saúde e um porto em toda sua extensão para atracação de embarcações.

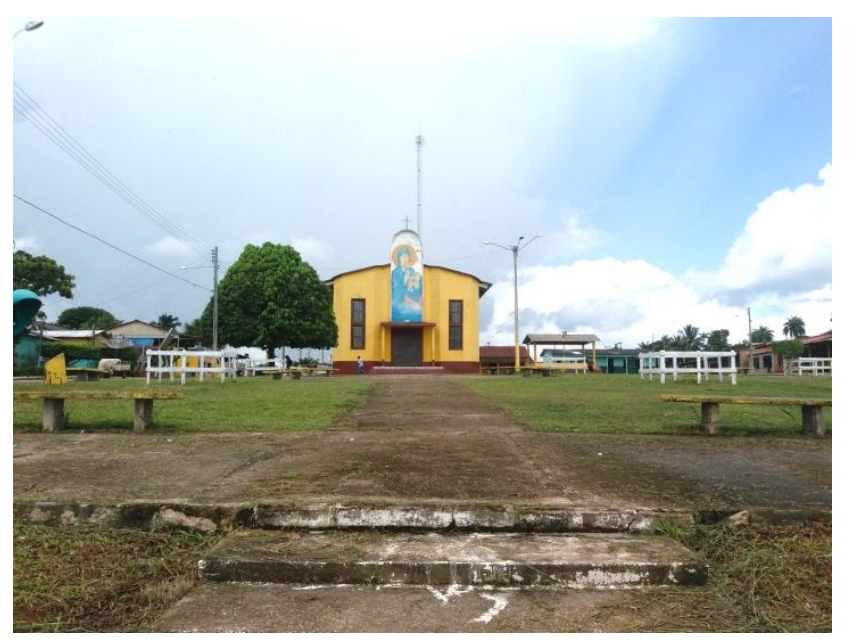


Foto 4 - Igreja Bom Socorro do Zé Açú

Pesquisa de Campo, 2016.

Com ruas e avenidas pavimentadas e nomeadas, a comunidade se orgulha em testemunhar o trunfo de um dia ter sido uma das comunidades exportadoras de banana. As festividades ficam por conta das honras à santa padroeira, Nossa Senhora do Perpétuo Socorro, e às quadrilhas que agitam a comunidade nos festejos de junho.

A comunidade do Zé Açú é frequentada com mais intensidade nos finais de semana em razão do potencial turístico que oferece, com suas praias e os igarapés de águas claras no meio da mata que se formam no leito das comunidades. O cenário compensa a distância para quem sai de Parintins e vai de lancha ou para quem segue por mais de uma hora em estrada de piçarra ${ }^{11}$ pela Vila Amazônia subindo e descendo ladeiras.

A economia que prevalece na comunidade do Zé Açú é a da pesca e da agricultura. A pesquisa de doutorado de Silva (2015) revela que a atividade pesqueira é a principal fonte de sobrevivência do povo que mora ali, pois serve como complementação alimentar na dieta diária enquanto a agricultura está voltada para a comercialização dos produtos agrícolas.

A agricultura e a pesca tem sofrido os impactos negativos da ação humana, seja pela queima do pasto por agricultores comerciantes, o que resulta no desmoronamento dos barrancos nos lagos, seja pela pesca predatória, que afeta o equilíbrio ecossistêmico e faz com que os peixes estejam cada vez mais difíceis de encontrar.

Os programas sociais de transferência de renda, especialmente o bolsa família, tem sido a principal fonte de rendimento na comunidade. Uma das condicionalidades impostas pelo programa, de permanência das crianças na escola, contribui para que os filhos não acompanhem mais os pais na agricultura e na pesca como acontecia com as gerações anteriores.

A valorização da educação pelas famílias rurais do Zé Açú tem sido pauta de reivindicação das lideranças comunitárias, que reconhecem nos estudos a possibilidade de se ter uma vida melhor, diferente de vinte ou trinta anos atrás em que as pessoas

\footnotetext{
${ }^{11}$ Tipo de solo à base de barro e pedras.
} 
precisavam ajudar os seus pais na roça e na pesca e depois assumir o sustento das famílias que constituíam.

A religiosidade é outro aspecto predominante no modo de vida do povo que vive no Zé Açú. As honras à Santa padroeira, Nossa Senhora do Perpétuo Socorro, mobiliza toda a comunidade para a organização da festa. Os comunitários se mobilizam para ornamentar a igreja e as ruas, na limpeza da praça, no preparo das comidas, na organização das brincadeiras, dentre outras atividades.

Essa solidariedade no contexto rural é importante porque faz com que as pessoas se sintam pertencentes a um mesmo contexto sociocultural envolvidos pela afetividade que desperta a solidariedade e a cooperação entre os seus membros. Por isso que, para Silva (2015:150), não se trata, apenas, de um momento de fé, mas de encontro, pois

[...] é antes de tudo, momento em que vizinhos, conhecidos, parentes que moram distante e até mesmo pessoas estranhas que vem de outros lugares, em que, muitas vezes há tempos não se comunicavam e que tem a oportunidade de se reencontrar em momentos como este. Aproveitam este momento de socialização, de descontração, de conversas, de lembranças e recordações de bons momentos já vividos, mas que sempre são agradáveis de relembrar, principalmente nesta época.

A dissertação (2009) e a tese de doutorado (2015) de Charlene Maria Muniz da Silva apontam que as comunidades rurais de Parintins descritas nesse texto, embora tenham assimilado elementos do urbano em suas infraestruturas, - refletidos no asfaltamento, equipamentos e serviços urbanos, nas mudanças na composição paisagística, nos modos de vida modificados e nas formas de trabalho não mais ligadas somente ao campo - preservam elementos do rural (não como antigamente) nas relações sociais e na relação com o ambiente natural, como a forma de falar, a relação com o ambiente, as matas, os rios e as relações de parentesco e solidariedade.

\section{Imaginários e vivências dos velhos das comunidades rurais de Parintins,}

\section{Amazonas}


Os "antigos”, como se chama nas cidades do interior da Amazônia, ou melhor, os velhos são sujeitos que ao longo de suas trajetórias de vida tiveram as suas práticas sociais envolvidas na dinâmica social das comunidades rurais. A vida do velho que mora nas comunidades rurais de Parintins é marcada pelo trabalho enquanto meio de sobrevivência e pela religiosidade que, como vimos, é tanto expressão de fé como também mecanismo de socialização.

A fé do homem do interior ${ }^{12}$ da Amazônia não é somente nos santos católicos para a concessão de graças ou no plano da salvação do cristianismo. Os velhos tem o seu imaginário aguçado pela crença em seres míticos que se manifestam em forma de visagens e em seres que se engeram ${ }^{13}$.

Para Galvão (1976:64), existem crenças arraigadas na mente do “caboclo” que “não podem ser postas de lado sob a alegação de que se trata de superstições ou de sobrevivência pagãs, porque são igualmente ativas e capazes de despertar atitudes emocionais e místicas na mesma intensidade que as do corpo de catolicismo”.

As visagens são aparições ligadas a seres sobrenaturais que tem a pretensão de estabelecerem contato com o homem para transmitir-lhe alguma mensagem. Essas aparições podem ter forma de bicho, de gente, ou podem não ter forma alguma, apenas deixar rastros, podem também ser anunciadas por meios de cantos de pássaros, do balançar das folhas das árvores e despertar arrepios em quem as sentem por perto.

A narrativa de Beija-Flor (65 anos) revela a sua própria experiência no contato com visagens, conforme demonstrado a seguir:

\begin{abstract}
Conheço história de visagem. Eu nasci e fui criado aqui. Eu vi visagem diversas vezes. Olha, aqui nesse campo, quando eram dez horas da noite, a gente já estava deitado. Naquele tempo, tinha energia só até nove horas da noite e não tinha muito o que fazer. Aí se escutava quando passava um vaqueiro gritando: "éééhhhhhh". O pessoal foi acostumando e eu acredito que era visagem. Mas, o dono dessa terra disse que era mãe do campo, outros dizem que é encantado porque aqui deve ter ouro enterrado, essas coisas (ENTREVISTA, 2016).
\end{abstract}

Viver no "interior" é estar em contato frequente com a floresta e os rios. As visagens que aparecem para quem mora nas comunidades rurais advertem

\footnotetext{
${ }^{12}$ Expressão empregado para se referir ao sujeito que vive nas comunidades rurais.

${ }^{13}$ Se engerar é a capacidade de o indivíduo se transformar em um animal ou em um outro ser, que pode ser humano ou a uma figura mítica que faz parte do imaginário amazônico.
} 
comportamentos predatórios do homem com a natureza, como o desperdício e a ganância, e também anunciam mistérios que a natureza guarda.

O vaqueiro citado por Beija-Flor (65 anos) representa o guardião de um tesouro escondido no solo. Acredita-se que aonde esse espírito aparece há ouro escondido naquele local. A mãe do campo é um espírito que protege a mata e os animais de maustratos e que assombra quem extrai da floresta mais do que precisa para sobreviver dentro de um contexto racional do uso dos recursos naturais.

Os encantados são espíritos que vivem no fundo dos rios e que emergem de lá para fazer o bem ou o mal. Galvão (1976: 66) define encantado "como uma força mágica atribuída aos sobrenaturais. Seres humanos, animais, objetos podem ficar encantados com a influência de um sobrenatural”. Esses seres tem a habilidade de malinar ${ }^{14}$ das pessoas ou agir como espíritos curadores que encarnam nos pajés quando invocados em rituais de pajelança indígena ou cabocla.

A presença da visagem traz temor porque geralmente é prescindida de alguma consequência perturbadora ou doentia. Quando isso acontece, recorre-se às benzedeiras para que, através de suas rezas, o encanto seja desfeito. "Os bichos visagentos não recebem qualquer culto ou devoção. A atitude do caboclo é de evitá-los tanto quanto possível ou de recorrer a técnicas de imunização ou de neutralização de seus poderes malignos” (Galvão, 1976: 04).

As pessoas que se engeram é outra crença que existe no imaginário dos velhos que vivem nas comunidades rurais de Parintins. Eles contam que já viram ou já ouviram histórias de pessoas que se transformam em animais ou em seres míticos. Alguns, inclusive, apontam seus próprios vizinhos como pessoas que se engeram e que conseguiram identificar-lhes após oferecerem agrados para afastar a presença do ser engerado e logo após viram o mutante em sua forma humana, conforme é possível acompanhar nas narrativas:

Olha, aqui, eu ainda não vi, afora antes eu já ouvi falar. Tinha um velho que se engerava pra matim. Uma vez o meu pai amarrava uma linha comprida que apoiava a terra que arriava. Quando foi uma noite o matim cantou, e aí ele correu na corda da rede e deu um laço e disse: olha, matim, amanhã vem buscar teu tabaco!. Aí quando foi de manhã, o papai saiu pra fora e foi ver a linha, tava arriada, juntou toda a linha e deixou lá e botou na canoa, aí nem

\footnotetext{
${ }^{14}$ Fazer maldade.
} 
demorou ele chegou, um conhecido nosso, veio pegar a corda. Era ele que era o matim, inclusive o filho dele mora ali (GAVIÃO, 71 ANOS, ENTREVISTA, 2016);

Olha, tem um homem aqui que diz que se engera pra cavalo. De vez em quando ele passa aqui, é um que chamam Hugo. Eu nunca vi. Mas, tive uma sobrinha que já até morreu, que ela disse que viu ele cair na terra, se enrolar e se levantou um cavalo (ANDORINHA, 71 ANOS, ENTREVISTA, 2016);

Já ouvi falar que se engeravam pra porca aí na beirada, mas já morreu (ÁGUIA, 75 ANOS, ENTREVISTA, 2016);

Eu ouvi falar um tempo que se engeravam, mas não sei se é verdade não. Uma senhora diz que se engerava pra porca, outra se engerava pra um cavalo (PAPAGAIO, 66 ANOS, ENTREVISTA, 2016);

Diz que pra ali tem um homem que a mulher largou porque ele se engerou pra cachorro (ROSA, 97 ANOS, ENTREVISTA, 2016).

Para Wawzyniak (2012), “engerar” é uma categoria nativa usada pelos ribeirinhos da Amazônia e que indica o caráter transformacional dos corpos e de comportamentos dos seres humanos para bichos ou seres míticos e não humanos para humanos. Assim,

Frequentemente eles permanecem invisíveis, sinalizando sua presença através de sons, "assobios", "pitiú" (odores característicos de cada ser ou de determinados estados) ou "misura" (capacidade do bicho se manter invisível, mas manifestar sua presença sob diferentes "formas" à pessoa da qual ele se aproxima) (Wawzyniak, 2012: 23).

O demiurgo “Matim” relatado por Gavião (71 anos) é, na verdade, Matinta Perera que, segundo conta a lenda amazônica, é uma bruxa velha que se transforma a noite em um pássaro agourento que pousa nos telhados das casas a assobiar até o morador se sentir incomodado e lhe prometer café, tabaco, cachaça ou peixe desde que ele vá embora. No outro dia, a velha vai até a casa do morador cobrar a promessa. Caso não seja cumprida, é possível que se anuncie uma desgraça.

As narrativas dos velhos das comunidades rurais de Parintins mencionam e inferem sobre "velhos que se engeram", geralmente em porcas e em cavalos. A dimensão metafórica dessa metamorfose pode residir no fato de que os próprios velhos desses lugares são enxergados pelas crianças e jovens como bruxas, no caso das velhas, e homens maus, no caso dos velhos, como eles próprios relatam. A ideia dos velhos como seres perversos e assustadores está arraigada no imaginário regional construído 
desde a infância com a ideia do velho do saco que vai pegar a criança que não se comporta e da bruxa que come criancinha.

As visagens e os mitos fazem parte da vida do povo que vive na área rural da Amazônia. O sistema cultural é, segundo Wawzyniak (2012), povoado por uma pluralidade de agentes humanos e não humanos que estabelecem relações sociais e essas relações afetam a vida cotidiana individual e coletiva. Constam nessas relações parâmetros éticos sobre como lidar com o outro e uma ética de responsabilidade com o meio ambiente e as gerações futuras na ótica da sustentabilidade e no manejo consciente dos recursos naturais. Morin (2012) refere que, assim como a lógica está para a racionalidade, o mito está para a analogia. Nas sociedades arcaicas, os mitos orientavam os "primitivos" nas estratégias de caça e na aquisição de conhecimentos, o que demonstrava a inteligência e as práticas racionais desses povos.

A toada “Contos Caboclos” do boi Garantido de Parintins (2007, Álbum “Guardiões da Amazônia”) traduz poeticamente o imaginário que permeia a vida do caboco do interior:

O rio aconchega a lua cheia

Pra flor de vitória despertar A noite se embala numa rede Pras suas histórias declamar ôôô

A vida de gente da floresta

É rica de contos e quimeras Tem bicho encantado no poção Visagem, Matim, Assombração

E a noiva da madrugada ôôô Tem gente que se engera em bicho Quem acha um tesouro escondido Não olha pra trás Eu sou o rio, sou o luar Eu sou as histórias do lugar Eu sou caboclo ribeirinho Sou filho de Yara e de boto Eu sou o rio, sou o luar

Eu sou os mistérios da mata Do imaginário do povo

Apesar do temor aos seres sobrenaturais, a comunidade não busca neles a proteção que precisa, e sim no Divino, representado pelos santos católicos padroeiros da localidade ou na fé protestante em Jesus Cristo. A proximidade dos velhos com a religiosidade nas comunidades rurais de Parintins é motivada pela necessidade de viver 
mais e com saúde, na remissão dos pecados cometidos ao longo da vida e na redenção da alma após a morte, mas também pelo prazer da espiritualidade e de poder contribuir com as atividades da igreja.

Dessa forma, Monteiro (2004: 59) explicita que:

Ao envelhecer as ilusões vão se desvanecendo, e a vida com seu mistério se coloca com mais realidade diante de nossos olhos, corrigimos inverdades, ressignificamos vivências e até podemos tentar olhar a morte. Seja qual for o rumo vivido pelo sujeito é a dimensão espiritual que lhe dá a sustentação.

Sem grandes atrativos de sociabilização no "interior"15, os velhos dedicam-se às atividades da igreja como forma de doação a Deus. Os atos festivos são momentos que mobilizam a comunidade e impulsionam o convívio. As festas dos santos são as mais frequentadas. Quando coincidem com o mês em que se comemoram os festejos juninos, é possível também ver a presença dos velhos, não de forma expressiva como nas festas dos santos.

Em algumas comunidades rurais existem outras festas que promovem concursos de beleza e que celebram a colheita e as praias que se formam no verão. Mas, como são consideradas profanas, os velhos optam por não participarem, pois entendem que já chegaram a um momento da vida que, além de não terem mais vigor para acompanhar o ritmo de interação que ocorre nessas festas, também consideram que o teor delas pode lhes afastar da santidade que tanto prezam em suas idades através da aproximação com o Divino, a quem são gratos por terem alcançado a idade que chegaram e por não lhes faltarem nada para viver. Orquídea (69 anos) relata que “eu não ganhava nada com isso, eu dançava muito, bebia muito. Até digo para as minhas irmãs e para o padre como eu mudei, que eu era complicada, trabalhosa. Mudei. Mudei mesmo” (Entrevista, 2016).

A religiosidade e a fé fazem parte da vida dos velhos não apenas nos cultos, nas missas e nas festas dos santos. A fé também é o alicerce nas práticas dos velhos e das velhas rezadeiras e curadores (as) nas comunidades rurais de Parintins embora os rituais católicos e protestantes não se misturem com os rituais de benzição e de cura, alicerçados nos saberes da pajelança indígena. Para Galvão (1976: 89):

\footnotetext{
${ }^{15}$ Referimo-nos às comunidades rurais, como são conhecidas pelos indivíduos que moram na área urbana de cidades do interior.
} 
As rezas ou orações que usam diferem daquelas do ritual católico no seu sentido que não constituem invocações por meios de comunicar-se com a divindade, mas possuem em si próprias o poder de curar. A forma e o conteúdo das rezas varia segundo o praticante e a situação específica para que são destinadas.

As benzedeiras e os (as) curadores (as) são mais procurados na área urbana de Parintins do que nas comunidades rurais que fizeram parte desta pesquisa. Os próprios velhos da área rural afirmam recorrerem aos médicos e aos remédios farmacêuticos quando adoecem. Essa questão pode estar associada à expansão dos serviços assistenciais na área rural e, no caso da saúde, à Estratégia Saúde da Família (ESF) em que o agente de saúde visita às casas dos usuários para acompanhar o quadro de saúde dessas pessoas.

Isso não quer dizer que os velhos não procurem as benzedeiras e os (as) curandeiros (as), principalmente aqueles que dizem não gostar de hospital porque associam esse lugar à ideia de doença e morte. Além disso, não deixam de fazer uso dos chás das plantas medicinais que cultivam no quintal de casa, como ilustra Tulipa (86 anos): "Eu faço chá de girataia e sucuba. São tudo casca de pau, fica tudo no mato. Eu faço banho de tudo, o pelé-pelé é bom para diabetes. E também banho de cuiamançu que eu tenho aqui no meu quintal” (Entrevista, 2016).

A procura pelas benzedeiras e pelos (as) curadandeiros (as), como os puxadores que corrigem distorções musculares (“rasgadura”), é motivada, principalmente, nos casos em que os serviços de saúde não contam com os recursos necessários para dar resolutividade ao problema.

O benzedeiro Galo da Serra (65 anos) conta como procede quando recebe casos de pessoas que relatam estar com “rasgadura”. Primeiro, ele reza o Pai Nosso, Creio em Deus Pai e Ave Maria sete vezes, depois benze em nome de Cristo. Feito isso, continua rezando em voz baixa enquanto costura um pedaço de pano com uma agulha e estabelece o seguinte diálogo com o benzido:

Benzedor: Quem eu benzo? Benzido: Sou Maria das Dores.

Benzedor: O que eu costuro? Benzido: Carne rasgada. (ENTREVISTA, 2016). 
Após repetir sete vezes esse ritual, o benzedor e o benzido acreditam que a “rasgadura” que estava alojada no corpo do benzido passa para o pano. O benzedor dá sete vezes o nó no pano e depois entrega ao benzido para que ele leve a uma árvore de nome sucubeira e seja fincado nela com a ponta de uma faca.

De acordo com Nonato et. al. (2016), as rezas proferidas por esses (as) benzedeiros (as) são diferentes daquelas que se fazem nas igrejas, sobretudo na igreja católica, com as ladainhas e as novenas. As rezas de cura invocam com autoridade espiritual a doença alojada para que ela se desprenda do corpo do indivíduo.

Outra figura importante nas comunidades rurais é a da parteira, ainda muito presente em razão das dificuldades logísticas e financeiras para se chegar à área urbana e acessar a maternidade. Acredita-se que quanto mais velha a parteira, mais experiente ela é, maior credibilidade ela possui na comunidade. Assim como a atividade da benzedeira e do (a) curandeiro (a), a parteira também é movida pelo altruísmo.

Vitória-Régia (90 anos) relata as dificuldades encontradas na realização do ofício, que demanda disponibilidade de tempo tanto para se deslocar até a casa da parturiente quando para permanecer com ela durante todo o trabalho de parto, especialmente quando ela apresenta complicações, conforme relata:

\footnotetext{
Eu fui parteira. Hoje em dia eu parei. Eu ia lá e às vezes a mulher ainda não ia ter e era aquela dor e eu achava ruim. Mas, aquelas que tinham logo eu achava bom. Eu fui parteira todos esses anos e eu partejei todas essas crianças que estão andando por aí. Mas, é muita criança! Quando eu olhava e pegava a barriga da mulher, eu sabia quando estava direito, quando não estava, aí eu começava a partejar. Eu tinha às vezes que sair uma semana para ficar com a pessoa (ENTREVISTA, 2016).
}

O rompimento com essa atividade após anos de prática revela o cansaço de Vitória-Régia por conta da idade (90 anos), mas também a satisfação de que cumpriu a sua função social ao trazer várias crianças ao mundo pelas suas mãos. O arrefecimento das forças físicas decorrente do declínio da capacidade funcional faz com que os velhos não disponham mais da “animação" (vigor), como eles dizem que tinham para continuarem exercendo os trabalhos que fizeram ao longo da vida, principalmente porque eram atividades que exigiam força e/ou resistência física.

O trabalho é considerado pelos velhos das comunidades rurais pesquisadas como fator de desgaste físico e acelerador da chegada da velhice em razão das condições 
insalubres e degradantes às quais precisavam se submeter no manejo manual. Ao longo de suas vidas ocuparam-se com as atividades no roçado, na agricultura, na pesca e na extração da juta para garantir a própria subsistência e a de suas famílias. As mulheres que ficavam viúvas tinham que se dedicar ainda ao cuidado dos filhos e aos afazeres domésticos.

Para os velhos entrevistados, o trabalho sempre foi uma obrigação necessária para a provisão das necessidades de subsistência da família e não uma atividade para acumular excedente e possibilitar a aquisição de bens de valor. As narrativas demonstram que eles começaram a trabalhar desde cedo, quando muito jovens, à medida que iam perdendo os pais e precisavam ajudar no sustento da família e depois, quando constituíam as suas próprias famílias, conforme demonstram as seguintes falas:

Para chegar à idade que eu estou, eu comecei a trabalhar muito, muito cedo, desde 15 anos que foi a idade que o meu pai faleceu e eu tive que assumir as contas. Eu comecei batalhando até hoje pela roça, pescando, em juta, essas coisas. Eu ganhei conhecimento sobre as pessoas, experiência e muitas coisas mais, informações, né? Eu perdi muita coisa, a sustança, já não tenho mais aquela força que eu tinha, de carregar peso, varar canoa, carregar... Aí eu já não tenho mais. Me sinto bastante já frágil, né? Mas, a gente não é mais como a gente foi pela idade "normal". [...] E eu trabalhei muito e fui envelhecendo assim (SURUBIM, 66 ANOS, ENTREVISTA, 2016);

Eu tive que cuidar muito da casa, cuidar dos filhos e tive que fazer de tudo. Eu tive onze filhos e tive que cuidar de todos eles. Eu trabalhava muito fazendo farinha e eles estudavam e eu tinha que ir para a roça. Eu tirava pra mais de dez sacos de mandioca e à noite, eu ainda costurava (JASMIN, 85 ANOS, Entrevista, 2016);

Chegar à velhice foi através de trabalho. Trabalhei muito em juta e muitos, muitos anos trabalhei em juta. Depois que parou a juta, nós viemos pra roça, terreno aqui no centro. Aí, nós trabalhava, fazia meu puxirum de 70, 80 pessoas pra plantar mandioca. E aí foi quando eu comprei uma carroça, comprei um cavalo, botei pra fazer corrida, naquele tempo não tinha carro, não tinha triciclo. Era nosso trabalho. Todo tempo vinham me chamar. Depois parei. Tive duas filhas, minha mulher morreu e eu passei a viver pro trabalho. Até hoje eu sinto dor na "cadeira", perdi força no olho, na minha visão (PICA-PAU, 76 ANOS, ENTREVISTA, 2016);

Ganhei os meus filhos e tudo que apareceu depois foi trabalhando, trabalhando pra sustentar no dia-a-dia. Desde quando comecei minha vida eu trabalhava, trabalhava na agricultura. Eu perdi, eu não construí nada com o trabalho, somente viver, né, e aí depois comecei a trabalhar em casa com os meus filhos sustentando. O que eu sinto que eu perdi foi a minha vista, a minha visão que eu perdi, mas graças a Deus eu ainda tenho vontade de fazer alguma coisa. Eu ainda trabalho, ainda capino, só não faço plantar, mas capinar, assear a casa... Graças a Deus, eu ainda me sinto assim, com ânimo de vida (HORTÊNCIA, 77 ANOS, ENTREVISTA, 2016). 
A fala de Hortência (77 anos): "Eu perdi, eu não construí nada com o trabalho, somente viver" é elucidativa sobre o sentido do trabalho atribuído pelos velhos das comunidades rurais de Parintins pesquisadas. A dedicação de suas vidas a atividades que exauriram as suas forças físicas lhes garantiram, apenas, o pão de cada dia, a sobrevivência. Para eles, o esforço empreendido não foi válido para amealhar recursos ou ter construído estabilidade financeira que garantisse um conforto melhor para viver a velhice.

Na área rural de Parintins, portanto, o trabalho dos velhos ao longo de suas vidas se voltou para prover as necessidades de subsistência de suas famílias. Esse sentido do trabalho nos faz lembrar Hannah Arendt quando discute a diferença entre "labor" e “obra”.

Para Arendt (2014), a concepção de "labor" (trabalho) difere da de “obra”. Enquanto “obra” (trabalho) é a atividade de transformação da natureza pela ação humana com a finalidade não só de satisfazer as necessidades humanas primárias, mas também, de criar um mundo artificial, pois produz objetos de valor e bens de consumo duráveis para além da breve existência humana, "labor" concerne à atividade responsável pela manutenção da vida. A relação homem-natureza se limita à sobrevivência e só se esgota com a morte do sujeito.

Realmente, é típico de todo trabalho nada deixar atrás de si, que o resultado do seu esforço seja consumido quase tão depressa quanto o esforço é despendido. E, no entanto, esse esforço, a despeito de sua futilidade, decorre de uma enorme premência e é motivado por um impulso mais poderoso que qualquer outro, pois a própria vida depende dele (Arendt, 2014: 107).

O conceito de "labor" parece-nos o mais apropriado para qualificar as atividades produtivas realizadas pelos velhos da área rural ao longo de suas vidas. Da terra e das águas eles tiram o sustento diário ${ }^{16}$ e, dessa forma, estabelecem relação de dependência com o meio em que vivem. Essa dependência leva-os a fixarem-se no lugar e construírem relações de sociabilidade com base na solidariedade, como é possível observar nos relatos a seguir:

\footnotetext{
${ }^{16}$ Da terra, por meio da agricultura, e das águas, por meio da atividade de pesca.
} 
Olha [eu não tenho vontade de sair daqui] não, porque eu tô na cidade e, de repente, eu tô em casa e vem um cara, mata minha esposa ou me mata. Aqui, não. Nós estamos mais libertos. Quer comer alguma coisa, empresta dos vizinhos, empresta uma farinha, e lá em Parintins ou [em] outra cidade, não. Se não tiver dinheiro, não come. Eu acho que vivo bem [aqui] e não me falta nada (ÁGUIA, 75 ANOS, ENTREVISTA, 2016);

Eu vivo [bem, aqui], mano porque não me falta nada. Peixe tem aqui na beirada. Tudo que eu quero comer, eu como (TULIPA, 86 ANOS, ENTREVISTA, 2016);

Rapaz, melhor do que isso, não dá. Estou vivendo bem, graças a Deus, porque eu como bem todo dia, tenho tudo o que quero, né? (GAVIÃO, 71 ANOS, ENTREVISTA, 2016);

Eu gosto bastante daqui porque, aqui, é minha casa. Vou na várzea, venho pra cá, e a gente já tem a propriedadezinha aqui. Pela força da gente, não dá pra ficar procurando outro lugar pra começar de novo, né? (PAPAGAIO, 66 ANOS, ENTREVISTA, 2016).

A relação homem-natureza ${ }^{17}$ não é, portanto, de cariz dominador, mas de dependência. O homem amazônida parintinense, sobretudo aquele que mora nas comunidades rurais, se relaciona com o meio em que vive como forma de dar respostas às suas necessidades materiais e espirituais. O religamento do homem com o seu meio é explicitado por Santos (2009) como forma de superação da fragmentação do saber, e, portanto, de uma relação de alteridade e dominação para formas mais elevadas de sociabilidade, que conjuguem solidariedade e cooperação.

Apesar do arrefecimento das forças que não lhes permitem mais ter “o ânimo de antigamente", ou seja, a força juvenil, os velhos das comunidades rurais de Parintins não aceitam serem chamados de "velhos" porque "ser velho é ser gasto e usado, pode ser jogado no mato, pode ser desprezado” (Tulipa, 86 anos, Entrevista, 2016), “é alguém debilitado, que não anda, não trabalha e não come sem a ajuda de outra pessoa” (Gavião, 71 anos, Entrevista, 2016), “uma pessoa desacreditada, imprestável, aquilo que a gente joga” (Rosa, 97 anos, Entrevista, 2016). E como "ainda não me jogaram fora” (Bicudo, 77 anos, Entrevista, 2016) e “não dou trabalho” (Hortência, 77 anos, Entrevista, 2016), os sujeitos envelhecidos da área rural não se aceitam como "velhos”.

O critério de utilidade é o que mede a vida do homem e da mulher do interior. As velhas continuam costurando, capinando, plantando e ocupadas com os afazeres domésticos. Os homens velhos ainda pescam, tecem malhadeiras e roçam. O ritmo das

\footnotetext{
${ }^{17}$ A natureza, no contexto de discussão deste trabalho, tem sentido do meio onde se vive.
} 
atividades não é mais o mesmo como na juventude e maturidade, mas eles provam que continuam ativos. Mas, para quê pressa, se assim como antes, continuam, "apenas”, vivendo no compasso de satisfação de suas necessidades? Uma vida sem pressa de ser vivida, uma vida na Amazônia.

4.

\section{Considerações Finais}

A velhice dispõe de características próprias, como traços físicos e comportamentos específicos, que atingem comumente a todos sem distinção, mas também é plural porque comporta heterogeneidades que diversificam as vivências dos sujeitos ao atingirem essa condição existencial, a partir de fatores como o gênero, a classe social, a saúde e, principalmente, a cultura.

A diversidade de velhices não permite restringi-la a um único modelo bemsucedido, como o de terceira idade, que se propaga como um ideal a ser atingido sustentando-se dentro de um tipo de gestão de serviços de consumo e de comportamentos juvenilizados que empobrece a pluralidade de vivências, pois não corresponde à realidade socioeconômica e cultural da maioria das pessoas velhas no Brasil, inseridas em contextos próprios.

Litvoc e Brito (2004) assinalam que a construção de uma velhice bem-sucedida contempla três aspectos, como a baixa probabilidade de doenças e o processo incapacitante decorrente delas, a preservação de uma boa capacidade funcional, tanto física quanto cognitiva, e a participação ativa na comunidade que, inclusive, pode resultar no fomento de uma atividade produtiva que contribua para que as pessoas mais velhas se mantenham ocupadas e possam complementar as suas rendas. Estes três fatores não dependem, necessariamente, que os indivíduos gozem de um certo poder aquisitivo para terem acesso às condições que propiciem estes aspectos.

Em Parintins, os precários serviços de saúde pública aliados à condição rebaixada dos serviços assistenciais de sociabilidade e à falta de uma política de emprego e renda na cidade não impedem que os velhos gozem de uma boa condição de saúde, que estabeleçam relações sociais com familiares e amigos e que se mantenham economicamente ativos. Para isso, usualmente recorrem à medicina tradicional, que sobrevive por meio das práticas de cura popular através das rezas e benzições e do uso 
de chás medicinais que contem propriedades de cura. Além disso, os velhos continuam trabalhando em atividades manuais, que embora sejam desgastantes e penosas, são necessárias tanto como forma de garantia do seu sustento e de suas famílias como, também, porque é uma forma de se manterem ativos no mundo da vida. Por meio do trabalho, estabelecem relações com outras pessoas, além dos seus circuitos familiares, o que corrobora para a manutenção de uma boa condição de saúde biopsicossocial.

Os velhos parintinenses tecem a poiesis de suas vidas na velhice acionando elementos do imaginário amazônico que permeiam as suas práticas sociais, sobretudo, no âmbito da religiosidade e da saúde. O temor e a fé não se limitam dentro de uma religiosidade única porque evoca elementos do sagrado e do profano constituídos no âmbito de uma cultura híbrida que congrega elementos da cultura indígena, europeia e nordestina que compõem a formação social da Amazônia. Vemos, então, o cristianismo andando junto com a pajelança indígena nos rituais de benzições e curas, no culto ao Divino e no respeito à sustentabilidade ambiental. De acordo com Ponce de Leão Nonato (2018:36):

\begin{abstract}
Os velhos são sujeitos que carregam em suas trajetórias de vida a construção de si ao longo do tempo e no lugar. A poiesis de suas vidas na velhice é orientada por um continuum traçado ao longo da vida e que é regido por valores e pelas escolhas realizadas, norteados pelos costumes e a moral vigentes em um determinado contexto sociocultural. A autopoiesis é uma experiência particular do indivíduo em um lugar particular, portanto, não pode ser generalizada ainda que outros indivíduos compartilhem de um mesmo meio, pois haverá outra significação e outra organização autopoietica.
\end{abstract}

Ser velho na Amazônia também resiste ao estigma estereotipado de quem não serve mais para nada. Mas, a forma de resistência não reside na adoção de comportamentos juvenilizados, e sim, no critério de utilidade social medido pela permanência no mundo do trabalho. O trabalho se constitui não só como uma atividade necessária para prover a subsistência, já que a maioria dessas pessoas não recebe nenhum tipo de benefício previdenciário ou assistencial, mas, principalmente, como elemento de permanência no mundo da vida, como atividade essencial de utilidade do ser, responsável por validar o indivíduo no meio em que vive como alguém necessário porque é produtivo. 
A Amazônia é o celeiro, portanto, não só da biodiversidade, mas, também, da sociodiversidade. Os velhos amazônidas que vivem nas comunidades rurais de Parintins elaboram as suas velhices de forma bem-sucedida evocando elementos do imaginário amazônico em suas práticas sociais conferindo-lhes sentido existencial às suas vidas no tempo-lugar em que se inserem. A valorização social dessas pessoas não se situa em conformidade com o modelo hegemônico de velhice conhecido como "terceira idade", mas pela participação social na comunidade em que os velhos vivem exercendo papeis de guardiães e perpetuadores dos saberes tradicionais que permitem a reprodução e a manutenção da vida de gerações atuais e futuras.

5.

Referências

ARENDT, Hannah. A condição humana. Tradução de Roberto Raposo. $12^{a}$ edição. Rio de Janeiro: Forense Universitária, 2014;

BRASIL. Instituto Brasileiro de Geografia e Estatística, 2010. Disponível em www.ibge.gov.br;

GALVÃO, Eduardo. Santos e Visagens: um estudo da vida religiosa de Itá, Baixo Amazonas. 2a edição. São Paulo: Editora Nacional; Brasília: INL, 1976;

LEÃO, Alice Alves Menezes Ponce de. Serviço Social e Velhice: perspectivas para o trabalho do assistente social na promoção à saúde do idoso. Manaus: EDUA, 2015;

LITVOC, Júlio e BRITO, Francisco Carlos. Conceitos Básicos. In: Envelhecimento Promoção e Prevenção da Saúde. Júlio Litvoc e Francisco Carlos Brito (orgs.). São Paulo. Editora Atheneu, 2004;

MATURANA, Humberto R.; VARELA, Francisco J. A árvore do conhecimento: as bases biológicas da compreensão humana. Tradução de Jonas Pereira dos Santos. São Paulo: Palas Athenas, 2001; 
MONTEIRO, Dulcinéa da Mata Ribeiro (autora e organizadora). Busca de sentido e significado existencial. In: Dimensões do Envelhecer. Rio de Janeiro: Livraria e Editora Revinter, 2004;

MORIN, Edgar. O método 5: a humanidade da humanidade. Tradução de Juremir Machado da Silva. $5^{a}$ edição. Porto Alegre: Sulina, 2012;

PONCE DE LEÃO NONATO, Alice Alves Menezes. Sexo e Sexualidade na velhice: práticas transgressoras e negociadas no contexto amazônico (Tese de Doutorado). Universidade Federal do Amazonas. Manaus, 2018;

PONCE DE LEÃO NONATO, Alice Alves Menezes et. al. Entre o rural e o urbano: modos de viver a velhice em Parintins. Revista Eletrônica Mutações - RELEM, vol. 7, n. 13, 2016;

SANTOS, Boaventura de Sousa. Um discurso sobre as ciências. $6^{\text {a }}$ edição. São Paulo: Cortez, 2009;

SILVA, Charlene Maria Muniz da. Territorialidades rurais no município de Parintins: habitus, circularidade da cultura e ethos ambiental na localidade do Zé Açú. Tese de Doutorado. Programa de Pós-Graduação em Ciências do Ambiente. Manaus: Universidade Federal do Amazonas: 2015;

Mocambo, Caburi e Vila Amazônia no município de Parintins: múltiplas dimensões do rural e do urbano na Amazônia. Dissertação de Mestrado. Programa de Pós-Graduação em Geografia. Manaus: Universidade Federal do Amazonas: 2009;

WAWZYNIAK, João Valentin. Humanos e não-humanos no universo transformacional dos ribeirinhos do rio Tapajós-Pará. Revista Mediações, vol. 17, n. 1, p. 17-32. Londrina: 2012.

Recebido 23/04/2019

Aprovado 28/05/2019 